\title{
KREOWANIE NARODOWEJ PRZESTRZENI: O PIERWSZYCH INICJATYWACH WZNIESIENIA BELGRADZKIEJ ŚWIĄTYNI ŚWIĘTEGO SAWY W UJĘCIU PORÓWNAWCZYM
}

\author{
ALEKSANDRA FEDER
}

\begin{abstract}
Creating a national space: about the first initiatives of building the Belgrade temple of Saint Sava in a comparative approach.

In the article are considered ideological and identity aspects of the emergence of the initiatives to build an Orthodox temple dedicated to Saint Sava in Belgrade. The object was thought to become an emblem of the reconstructed Serbian identity, created on the basis of national and religious narratives from the 19th and 20th century. The issue is showed comparatively with the Ivan Meštrović artistic project entitled Vidovdanski Hram, dedicated to the idea of Yugoslav unity.
\end{abstract}

STRESZCZENIE. W tekście są rozważane aspekty ideologiczne i tożsamościowe pojawienia się pierwszych inicjatyw budowy prawosławnej świątyni pod wezwaniem Świętego Sawy w Belgradzie. W założeniu obiekt ten miał stać się emblematem serbskości rekonstruowanej w zgodzie z serbskimi tradycjami religijno-narodowymi, kształtowanymi w XIX i XX wieku. Zagadnienie to zostało przedstawione w porównaniu z projektem artystycznym Vidovdanski Hram, autorstwa Ivana Meštrovicia, hołdującym idei jedności jugosłowiańskiej.

Autor: Aleksandra Feder, Uniwersytet Warszawski, Instytut Slawistyki Zachodniej i Południowej, ul. Krakowskie Przedmieście 26/28, Warszawa, Polska, am.feder@uw.edu.pl, ORCID iD: https://orcid.org/0000-00020759-5022

Slowa kluczowe: Serbia, Świątynia Świętego Sawy, Vidovdanski hram, architektura, przestrzeń, tożsamość narodowa

Keywords: Serbia, Temple of Saint Sava, Vidovdan temple, architecture, space, national identity

Balcanica Posnaniensia. Acta et studia, XXVII, Poznań 2020, Wydawnictwo Wydziału Historii UAM, pp. 137150, ISBN 978-83-66355-54-5, ISSN 0239-4278. Polish text with summaries in English and Polish.

doi.org/10.14746/bp.2020.27.9

Wiek XIX przyniósł Serbii długo wyczekiwane wyzwolenie spod panowania Imperium Osmańskiego. Organizacja struktur państwowych oraz rekonstrukcja narodowego imaginarium symbolicznego stanowiły części składowe procesu odzyskiwania politycznej niezależności. Księstwo, a następnie królestwo konsolidowało się wpierw pod berłem dynastii Obrenoviciów, a później Karađorđeviciów. Przełom XIX i XX wieku można też uznać za czas intensywnej urbanizacji serbskiego terytorium. 
Ówcześni władcy stanęli przed, prymarnym w swoim znaczeniu, wyzwaniem zmodernizowania i przystosowania poosmańskich ośrodków miejskich do europejskiego (a nie tureckiego) stylu architektonicznego ${ }^{1}$.

Przestrzeń w procesie rozwoju urbanistycznego i społecznego - a zwłaszcza dynamiczna przestrzeń publiczna - posiada imponujący potencjał, by zostać nośnikiem ideologii. Jest ona zwierciadłem, w którym odbijają się zarówno wszelkie wizje polityczne, jak i kompleksy społeczne. Nowo wznoszone budowle wielokrotnie jawią się jako elementy skrupulatnie zaprojektowanego systemu symbolicznego. Znaczenie kultury i sztuki w procesie kreowania tożsamości narodowej jest ogromne, gdyż - jak wskazuje historyk sztuki Nenad Makuljević - sztukę można traktować jako ucieleśnienie i świadectwo istnienia duchowego wymiaru narodu, jak również sposób kreowania narodowej tożsamości ${ }^{2}$ Próbując podążać tropem myślowym serbskiego badacza, należy zadać kluczowe, konkretyzujące pytanie, a mianowicie - kto lub co wspomniany „duchowy wymiar narodu” określa i próbuje konceptualizować? Przecież nie przejawia się on sam przez się, a jednak może kryć się np. w przedstawieniach sławetnych bitew, jak też w wyrafinowanych formach architektonicznych. W przestrzeni symbolicznej, konceptualno-memorialne kompozycje (wliczając do nich również obiekty sakralne) jawią się jako elementy sztuki zideologizowanej - odwzorowującej oraz aktywnie kreującej nową rzeczywistość polityczną, społeczną i kulturową. Wszak „architektura - co podkreśla historyk projektowania Deyan Sudjic - jest przede wszystkim sposobem na opowiedzenie o tych, dzięki którym powstaje ${ }^{3 "}$.

W przypadku serbskich miast końca XIX i pierwszych dekad XX wieku przemiany architektoniczne zachodziły paralelnie do konstruowania nowoczesnej tożsamości państwa i narodu. Zdaje się zatem uzasadnione uznawanie architektury za wizualną i materialną afirmację narodowej/etnicznej/religijnej identyfikacji. Problem serbski jest dodatkowo złożony, ponieważ z jednej strony podejmowano próby wyznaczenia i zdefiniowania stylu architektonicznego, który miałby pozostawać podporą ideologiczną Królestwa Serbii, przez co pozytywnie i konsolidująco wpływałby na tę wspólnotę, tj. serbską wspólnotę narodową i co ważne - religijną. Z drugiej zaś strony, przełom wieków, a w szczególności pierwsza połowa XX wieku to czas pojawienia się na Półwyspie Bałkańskim nowej jednostki państwowej - politycznie zespolonego pod berłem Karađorđeviciów królestwa Słowian południowych, sklejo-

${ }^{1}$ Podstawowym przykładem, w jaki sposób przebiegał proces europeizacji i modernizacji poosmańskich miast jest stołeczny Belgrad, zob. D. Stojanović, Kaldrma i asfalt: Urbanizacija $i$ evropeizacija Beograda 1890-1914., Beograd 2012. (Należy wyraźnie zaznaczyć, iż celowo w dyskusji o „przystosowywaniu ośrodków miejskich" nie wspominam o stylistycznie środkowoeuropejskich terenach Wojwodiny, gdyż zjednoczyły się one z ziemiami serbskimi dopiero w 1918 roku).

2 N. Makuljević, Jugoslovenska umetnost i kultura. Od umetnosti nacije do umetnosti teritorije, w: Jugoslavija u istorijskoj perspektivi, red. L. Perović, D. Roksanović, M. Velikonja, W. Hoepken, F. Bieber, Beograd 2017, s. 415.

3 D. Sudjic, Kompleks gmachu. Architektura władzy, przeł. A. Rasmus-Zgorzelska, Warszawa 2015, s. 14. 
nego z różnych narodów, a tym samym elementów symbolicznych, religijnych i ideologicznych. Serbowie byli częścią tej skomplikowanej układanki. Kreatorzy nowo powstałego podmiotu politycznego dążyli do rozpowszechniania integrujących społeczność symboli i treści, które składałaby się z wątków uniwersalnych dla wszystkich tworzących go grup etnicznych i wyznaniowych. Właśnie ze względu na przytoczone pokrótce dwa poziomy funkcjonowania Serbii początku XX wieku, analizę wszelkich znaczących projektów architektonicznych warto prowadzić w ujęciu porównawczym, które pozwala lepiej zrozumieć ich symboliczną i kompozycyjną złożoność.

W przypadku niezależnego państwa serbskiego kodyfikacja języka wizualnego nosiła znamiona dualizmu. Opierała się bowiem na poszukiwaniach kontinuum tożsamości narodowej, czyli spoglądaniu w przeszłość i wskazywaniu fundamentalnego Złotego Wieku, przy równoległym dążeniu do intensywnej modernizacji, która wyznaczyłaby narodowe ,tu i teraz” oraz określała przyszłość tejże wspólnoty. Te poszukiwania autentyczności i ciągłości, podparte doskwierającą potrzebą funkcjonowania w kręgu nowoczesnej europejskiej cywilizacji objawiły się w postaci form architektonicznych zawierających w sobie zarówno cechy bizantyjskie, jak i zachodnie. Jako przykład obiektów o dualnej tożsamości, historyk architektury i sztuki Aleksandar Ignjatović wskazuje np. cerkiew św. Georgija w Smederevie z 1855 roku ${ }^{4}$. W przestrzeni Belgradu zaś można zwrócić uwagę na kontrast stylistyczny pomiędzy dwoma obiektami sakralnymi - bardziej „europejskim” w swojej formie Soborem św. Michała Archanioła (powstałym w pierwszej połowie XIX wieku) oraz odwołującą się do średniowiecznej tradycji Cerkwią św. Marka (wybudowana w pierwszej połowie XX wieku).

Określenie wzorcowego oblicza tzw. stylu serbsko-bizantyjskiego (nazywanego również współczesnym stylem serbsko-bizantyjskim) stanowiło kwestię dyskusyjną oraz podlegało politycznej i kulturowej dynamice owych czasów. Na co zwraca uwagę Ignjatović - powołując się na ideologów i architektów przełomu XIX i XX wieku - serbska „,bizantyjskość” przejawiała się wtedy poprzez odwołania do spuścizny „,szkoły morawskiej” 5 z XIV i XV wieku, a więc paradoksalnie z czasów kiedy serbskie państwo było w fazie schyłkowej. Sam styl serbsko-bizantyjski był wielokrotnie określany jako styl epoki księcia Lazara i despoty Stefana ${ }^{6}$. Zabytki szkoły mo-

4 A. Ignjatović, Između žezla i ključa. Nacionalni identitet $i$ arhitektonsko nasleđe Beograda $i$ Srbije u XIX i prvoj polovini XX veka, „Nasleđe” 2008, nr 9, s. 51.

5 Szkoła morawska to określenie tendencji w średniowiecznej sztuce drugiej połowy XIV i początków XV wieku w Dorzeczu Morawy. Kształtowała się w czasach ostatnich serbskich środowisk państwowych i kulturowych, czyli za panowania księcia Lazara Hrebeljanovicia i później pod zwierzchnictwem Lazareviciów i Brankoviciów. Zabytki tradycji morawskiej cechowała stylistyczny eklektyzm, nawiązująca zarówno do stylu raszkańskiego, jak i macedońskiego, a za jej reprezentatywne formy można uznać np. cerkiew Lazaricę i cerkiew monasteru Ravanica (obie wybudowane pod koniec XIV wieku). Zob. W. Molè, Sztuka Słowian Południowych, Wrocław-Warszawa-Kraków 1962, s. 79-83.

6 Por. A. Ignjatović, op. cit., s. 61. 
rawskiej pozostawały stylistycznie bliskie budowlom dawnego kręgu bizantyjskiego, a przede wszystkim obiektom architektury serbsko-macedońskiej ${ }^{7}$.

Unaocznianie cech bizantyjskich w przestrzeni lokalnej wiązało się również z powracającą refleksją nad panowaniem i spuścizną kulturową mocarstwa cara Dušana jedynego „cesarza” Serbów (i Greków - zgodnie z nadanym sobie tytułem), za którego panowania granice państwa sięgały Epiru i Tesalii. To właśnie jego postać na początku XX wieku przywoływali zwolennicy bizantynizacji rodzimej kultury, wzmacniając społeczne wyobrażenie o potędze Nemanjiciów. Liczne przejawy serbskiej bizantyjskości w zamierzeniach jej propagatorów miały sytuować Serbię wśród spadkobierców bałkańsko-prawosławnej tradycji, uznawanej za rdzenną i szlachetną. Bezpośrednie nawiązania do spuścizny średniowiecznego państwa serbskiego, czerpiącego z bizantyjskich wzorców politycznych i kulturowych, pozwalały konstruować wspólnotę symboliczną szerszą i silniejszą niż wspólnota południowosłowiańska wspólnotę postbizantyjską. Stanowiłaby ona zatem grupę czerpiących ze spuścizny Bizancjum państw - poczet odradzających się imperatorów (m.in. Serbów, Bułgarów, Greków), którzy między sobą rywalizowaliby o miano „równiejszego wśród równych" czy raczej najbardziej autentycznego wśród autentycznych, tego prawdziwego sukcesora bizantyjskiego tronu ${ }^{8}$. Bizantynizacja kultury jawiła się więc jako wybór szeroko pojętych korzeni kulturowych, dzięki którym stereotypowy, orientalizowany, a przede wszystkim niedoceniony bałkański „dzikus” mógł dokonać samoprzeobrażenia w nowoczesnego człowieka kultury - kultury, w jego mniemaniu, nie gorszej niż ta zachodnia.

Istotną, o ile nie najistotniejszą, częścią składową przestrzenno-wizualnej przemiany było pozbycie się elementów stanowiących o wielowiekowej obecności „dzikiego”, „obcego” i „orientalnego” Imperium Osmańskiego. Wyburzanie świątyń muzułmańskich wizualnie stanowiło proces deosmanizacji ${ }^{9}$ Serbii. Swoista „demeczetyzacja”, będąca sposobem wizualnego porządkowania, a nawet „sprzątania” między innymi belgradzkiej przestrzeni, zapoczątkowała nową fazę, którą per analogiam nazwę fazą intensywnej „,cerkiewizacji”. Stanowiła ona wyraz symbolicznego mapowania terenu - semiotyzacji przestrzeni - „odzyskiwania” tego co niegdyś zostało utracone, a wręcz „skradzione”. Architektura świątyń prawosławnych - co potwierdza Ignjatović - pełniła istotną funkcję w wyznaczaniu konturów serbskiej tożsamości narodowej ${ }^{10}$. Wznoszone w XIX oraz na początku XX wieku cerkwie posiadały

7 Określnie ,architektura serbsko-macedońska” zaczerpnięte z: W. Molè, op. cit., s. 74-79. Należy zwrócić uwagę, że architektura serbsko-macedońska czy też styl serbsko-macedoński, nazywane są również stylem serbsko-bizantyjskim lub precyzyjniej - dawnym stylem serbsko-bizantyjskim (w odróżnieniu od współczesnego, rozwijającego się od XIX wieku), co może wprowadzać poczucie terminologicznego zamieszania.

8 A. Ignjatović, Ispred vizantijskog purpura: vizuelizacija nacije na Drugom vizantološkom kongresu u Beogradu 1927. godine, „Zbornik Matice srpske za likovne umetnost” 2018, t. 46, s. 129.

9 A. Ignjatović, Između žezla, s. 53.

10 Ibidem, s. 53. 
wszelkie konceptualne i wizualne predyspozycje, aby uznawać je za, posługując się językiem Sudjicia, podstawowe elementy ,stwarzania estetyki narodu ${ }^{11}$ ”.

Jednym z najbardziej spektakularnych projektów architektonicznych, pozostającym zarazem przejawem wspomnianej „cerkiewizacji” przestrzeni modernizowanego Belgradu, była inicjatywa wzniesienia monumentalnej w swojej formie i wymiarze symbolicznym świątyni pod patronatem świętego Sawy. W 1895 roku przedstawiciele belgradzkiej elity oficjalnie powołali do życia stowarzyszenie obywatelskie (jego pełna nazwa w języku serbskim: Društvo za podizanje Hrama Svetog Save na Vračaru), którego cel stanowiło zainicjowanie budowy tego obiektu sakralnego. Najbardziej adekwatnym miejscem do realizacji projektu wydawał się belgradzki Vračar - funkcjonujący w rekonstruowanym w XIX wieku serbskim imaginarium jako przestrzeń miejska nacechowana wyjątkową symboliką. Wedle sugestii i ustaleń ówczesnych badaczy to na tym wzgórzu w XVI wieku Turcy dokonali spalenia szczątków świętego Sawy, czołowego przedstawiciela rodu Nemanjiciów ${ }^{12}$. Święty Sawa to postaćsymbol, która jest nierozerwalnie związana z serbską tradycją religijną, kulturową i państwową ${ }^{13}$. Nowa aranżacja przestrzeni, która niegdyś symbolizowała upokorzenie narodu, miała dać sygnał do duchowego odrodzenia i zjednoczenia politycznej wspólnoty.

$\mathrm{Na}$ początku warto pokrótce rozważyć samą kwestię nazewnictwa. W założeniach pomysłodawców powstać miał hram (świątynia), a nie zwykła crkva (cerkiew) świętego Sawy. Co więcej, belgradzki obiekt został również określony mianem światyni pamięci (serb. spomen-hram). Fakt ten może wskazywać, że szczegółowo projektowany i umyślnie kodyfikowany symbolicznie obiekt wyobrażono jako swoisty pomnik ku czci tegoż świętego. Dodatkowym argumentem przemawiającym za taką interpretacją jest kwestia wybudowania prowizorycznej tzw. Małej Cerkwi Świętego Sawy, która została uroczyście, w asyście króla, poświęcona 27 kwietnia 1895 roku. $\mathrm{Na}$ ten dzień przypadała rocznica spalenia szczątków świętego Sawy. Powstały na Vračarze w niespełna tydzień obiekt przypominał swoją formą cerkiew monasteru Mileševa, czyli miejsce pochówku świętego. Mała Cerkiew, chociaż była regularnie rozbudowywana, miała stanowić jedynie tymczasowe rozwiązanie i zwiastować przyszłą budowę Świątyni ${ }^{14}$.

11 D. Sudjic, op. cit., s. 169.

12 Belgradzki Vračar funkcjonuje w serbskiej kulturze i mitologii jako miejsce spalenia relikwii świętego Sawy, jednak ustalenia dziewiętnastowiecznych badaczy są coraz częściej podważane. Istnieją teorie, że szczątki świętego Sawy nie zostały spalone na Vračarze, lecz w okolicach dzisiejszego Tašmajdanu (okolice Cerkwi św. Marka w Belgradzie). Dlatego w tekście zdecydowałam się na użycie określenia rekonstruowane $w$ XIX wieku serbskie imaginarium, gdyż wiele ugruntowanych współcześnie kodów symbolicznych wywodzi się właśnie z dynamicznych dziewiętnastowiecznych dyskusji, które prowadziły do reintepretacji tradycji, mitologii i tożsamości.

13 Zob. obszerniej: D. Gil, Prawosławie. Historia. Naród. Miejsce kultury duchowej w serbskiej tradycji i współczesności, Kraków 2005; D. Bandić, Narodno pravoslavlje, Beograd 2010.

14 Mała cerkiew istnieje również do dziś; https://hramsvetogsave.rs/O-Hramu/Istorijat-crkve [dostęp: 15.04.2020.] 
Nie bez znaczenia pozostawało pytanie o kształt architektoniczny samej świątyni. Założenia projektowe z początku XX wieku były nad wyraz monumentalne jak na warunki ówczesnego Belgradu, który dopiero zaczął podążać ścieżką monumentalizowania swego krajobrazu. Nawet z dzisiejszej perspektywy wizja inicjatorów zdaje się odważna. Plany zakładały, że świątynia rozrośnie się do imponujących rozmiarów i nie będzie miała sobie równej w regionie. Kwestia ta przynosi kolejny argument, by sądzić, że wraz z ewolucją narodowej myśli, belgradzka świątynia miała odgrywać symboliczną rolę domu serbskiego prawosławia, określonego w latach dwudziestych XX wieku przez biskupa Nikolaja Velimirovicia mianem świętosawia (serb. svetosavlje), które opiera się na średniowiecznej serbskiej tradycji prawosławia oraz czci naród, ze szczególnym uwzględnieniem kultu przodków, na których na czele stoi patron i duchowy autorytet - święty Sawa, pierwszy biskup i założyciel autokefalicznej Serbskiej Cerkwi Prawosławnej, najmłodszy syn wielkiego żupana Stefana Nemanji. Kult świętego odradzał się od XIX wieku, aby w latach późniejszych przekształcić się w prawdziwą religię narodową. Świętosawie stało się jednym z podstawowych wyznaczników narodowej/etnicznej identyfikacji $1^{15}$.

Dzięki usytuowaniu na wzniesieniu, projektowana, by górować nad innymi obiektami sakralnymi w mieście Świątynia Świętego Sawy miała wizualnie wyznaczyć centrum reaktywowanej serbskości - serbskie axis mundi - oś orientującą, a może nawet dyscyplinującą lokalną wspólnotę. Jako uzasadnienie tego stwierdzenia przytoczę fakt, że członkowie stowarzyszenia, którzy „programowali” przedsięwzięcie, stanowili belgradzką elitę (stu najbardziej szanowanych mieszkańców Belgradu; tłum. A.F. $)^{16}$, a na ich czele stał metropolita serbski Mihailo. Nie była to więc grupa przypadkowych urzędników bądź mieszkańców, którzy nie mieliby wpływu na kształtowanie nowoczesnej serbskiej tożsamości i norm obywatelskości. Wszak badacze zwracają uwagę, że to właśnie kręgi miejskich intelektualistów, konsolidowane przez hierarchów cerkiewnych, miały znaczący wpływ na kształtowanie się serbskiej myśli politycznej i narodowej pierwszych trzech dekad $\mathrm{XX}$ wieku ${ }^{17}$.

Pierwszy efekt działań belgradzkiego stowarzyszenia stanowiło rozpisanie w 1905 roku konkursu na projekt świątyni. Od aplikujących architektów pomysłodawcy wymagali, żeby przedstawione projekty były monumentalne w swej formie, powierzchnię obiektu szacowano na 2000-2500 metrów kwadratowych, a reprezentować miał on ciągle dyskutowany i krystalizujący się od XIX wieku styl serbsko-bizantyjski ${ }^{18}$. Można rozważać, na ile wymagania te wynikały z doświadczenia wieloletniego zniewolenia i konieczności ukrywania swojej tożsamości, które to czynniki

15 Zob. D. Gil, Świętosawski fundament kultury, w: idem, Prawosławie. Historia. Naród, s. 19-41.

16 Zob. Istorijat Hrama, https://hramsvetogsave.rs/O-Hramu/Istorijat-Hrama [dostęp: 15.04.2020].

17 Por. A. Kadijević, Sveta Sofija u Carigradu kao uzor srpskih arhitekata novijeg doba, „Zograf” 2019, nr 43, s. 215-16.

18 Zob. Istorijat Hrama. 
po zrzuceniu ,jarzma tureckiego" doprowadziły do manifestowania przynależności narodowej; można zastanawiać się, czy niczym niegdyś Osmanowie, tak później Serbowie i sama serbskość (serb. srpstvo) zdobywali Belgrad właśnie w ten sposób. Wszak najlepszym wizualnym symbolem zwycięstwa lub podboju jest wybudowanie twierdzy, która staje się centralnym punktem dowodzenia i obrony zdobytego terytorium, jak również skrywa oraz chroni najcenniejsze wartości. Potężna cerkiew wzniesiona w miejscu obrazoburczego aktu spalenia szczątków ponadczasowego patrona serbskości mogła spełniać te funkcje.

Postawionych przez pomysłodawców wymagań nikt nie spełnił i pierwszy konkurs nie został rozstrzygnięty. Na kolejny przyszło czekać kilkanaście lat, ponieważ sytuacja w regionie, zdominowana wojnami bałkańskimi, a następnie pierwszą wojną światową skutkowała zawieszeniem działalności stowarzyszenia. Dopiero po zakończeniu konfliktów, ukonstytuowaniu się nowego Królestwa Serbów, Chorwatów i Słoweńców oraz po formalnym zjednoczeniu Serbskiej Cerkwi Prawosławnej (SCP) w 1920 roku, reaktywowano inicjatywę. W 1926 roku już w nowej rzeczywistości społeczno-politycznej, gdy Belgrad stał się stolicą wieloetnicznego państwa, ogłoszono kolejny tzw. jugosłowiański konkurs na projekt świątyni, w którym udział mogli wziąc jugosłowiańscy architekci oraz przebywający w królestwie rosyjscy twórcy. Tym razem dookreślono, że obiekt ma być jeszcze większy (około 3000 metrów kwadratowych, przeznaczony dla 6 tysięcy wiernych). Komisja utrzymała wymóg stylu serbsko-bizantyjskiego - charakterystycznego dla budowanych na początku XX wieku świątyń prawosławnych i bezpośrednio odwołującego się do korzeni wielowiekowej serbskiej tradycji kulturowej. W założeniach konkursowych pojawił się jednak teoretycznie konkretyzujący zapis o uwspótcześnionym stylu serbsko-bizantyjskim, stylu epoki księcia Lazara ${ }^{19}$ [tłum. A.F.]. Datując epokę księcia Lazara na około drugą połowę XIV wieku i jej spuściznę przeciągającą się na wiek XV, wypada, że projekty nawiązujące do tego okresu powinny być wizualnymi reprezentacjami tradycji morawskiej.

Przedstawione komisji drugiego konkursu prace ukazały, jak nieoczywisty i niejednoznaczny pozostawał przypis, który w założeniach miał konkretyzować wymogi stylistyczne. Zamiast wzorować się na serbskich średniowiecznych zabytkach, architekci podążali ścieżką dominujących w ówczesnej sztuce neobizantyjskiej tendencji. Większość przedłożonych projektów swoją formą nawiązywało do kanonicznej Hagii Sofii, która w ówczesnej Europie inspirowała zarówno bałkańskich, jak i rosyjskich twórców ${ }^{20}$. Oprócz koncepcji replikujących bizantyjski prototyp, niektóre wyżej ocenione szkice wzorowane były na koncepcie kosowskiej Gračanicy, która też przecież nie reprezentuje bezpośrednio tradycji morawskiej, lecz - wedle histo-

19 Arhitektura Hrama, https://hramsvetogsave.rs/O-Hramu/Arhitektura-Hrama [dostęp: 15.04.2020].

20 Zob. A. Kadijević, op. cit., s. 220-227; A. Kadijević, Vizantijsko graditeljstvo kao inspiracija srpskih neimara novijeg doba/Byzantine architekcture as inspiration for serbian new age architects, Beograd 2016. 
ryka sztuki Wojsława Molè - architekturę serbsko-macedońską ${ }^{21}$. Stylistyczna nieoczywistość otworzyła wielowymiarową dyskusję na temat sposobów definiowania i rozumienia stylu serbsko-bizantyjskiego, przy założeniu, że jest on wykorzystywany w funkcji nośnika treści i poddawany ciągłemu oddziaływaniu społecznemu, politycznemu i ideologicznemu ${ }^{22}$.

Długie dyskusje członków komisji drugiego konkursu doprowadziły do wyłonienia najlepszego, choć wciąż nieidealnego w ich mniemaniu projektu. Oficjalnie nie przydzielono nagrody za zdobycie pierwszego i trzeciego miejsca, lecz premiowano koncepcję z drugiego miejsca, którego zdobywcą był Bogdan Nestorović (wzorujący się na Gračanicy). Wysoko oceniono również projekt Aleksandra Deroka (który nawiązywał do Hagii Sofii). Finalnie odpowiedzialność za budowę świątyni została powierzona temu duetowi ${ }^{23}$. Decyzja konkursowego jury miała wskazywać, że organizatorzy zaprzestali poszukiwania monumentalnych inspiracji w średniowiecznej architekturze sakralnej i sami zaczęli się skłaniać ku rozwiązaniom wizualnie bliskim prototypowej Hagii Sofii. Idea budowy Świątyni Świętego Sawy stała się faktem ${ }^{24}$. Prace zostały rozpoczęte w 1935 roku (już po wprowadzeniu dyktatury króla Aleksandra Karađorđevicia i jego zabójstwie podczas zamachu w Marsylii) i szybko, bo w 1941 roku przerwała je druga wojna światowa.

Kwestia budowy Świątyni Świętego Sawy wpisuje się w jedną z dwóch płaszczyzn funkcjonowania Serbii przełomu wieków XIX i XX. Gdy wewnątrz serbskich struktur państwowych stopniowo dokonywał się proces „bizantynizowania” kultury (oraz po części przestrzeni), walczące o swoją pozycję na Bałkanach królestwo Karađorđeviciów w swojej polityce zewnętrznej zaczęło skłaniać się ku koncepcjom zjednoczenia ziem zamieszkałych przez Słowian południowych, tym samym w pewnym stopniu spełniając swój sen o Wielkiej Serbii. Zwolennicy idei jugosłowiańskiej zyskali zatem aprobatę władzy i przestrzeń do rekonstruowania i reinterpretacji narodowych mitów w celu kreowania ujednoliconej kulturosfery, odpowiadającej koncepcji tzw. integralnego jugoslawizmu. Mechanizmy, którymi się posługiwali stanowią analogię strategii wykorzystywanych w przypadku tworzenia uniwersum symbolicznego monoetnicznej wspólnoty. Politycznie instrumentalizowana sztuka pozostawała jednym z czynników, który miał zacząć łączyć, a nie dzielić. Różnorakie formy arty-

21 Zob. W. Molè, Sztuka Stowian Poludniowych, Wrocław-Warszawa-Kraków 1962, s. 74-78. Badacz zwraca również uwagę, że niektóre architektoniczne elementy cerkwi monasteru Gračanica (1321r.) ponawiano w zabytkach tradycji morawskiej, a najlepszym tego przykładem jest forma monasteru Ravanica.

22 Problem kulturowej recepcji tzw. stylu serbsko-bizantyjskiego końca XIX i początku XX wieku obszernie podjął Aleksandar Ignjatović; zob. A. Ignjatović, U srpsko-vizantijskom kaleidoskopu: arhitektura, nacionalizam i imperijalna imaginacija 1878-1941, Beograd 2016. Warto zaznaczyć również, że na razie brakuje szczegółowych publikacji traktujących o np. rezonowaniu pojęcia „serbsko-bizantyjskości” przełomu XX i XXI wieku (a temat ten jest niewątpliwie godny uwagi badaczy).

23 Zob. Istorijat Hrama.

24 Aby zgłębić temat budowy oraz stylu Świątyni Świętego Sawy zob. B. Pešić, Godine Hrama Svetog Save, Beograd 1995. 
styczne wzbogacały plan wizualnej propagandy, konstruowany przez entuzjastów jugosłowiańskości i tworzenia estetyki jugosłowiańskiej. Wśród nich prym wiedli artyści i intelektualiści, którzy nie posiadali znaczącej partyjnej przeszłości w XIX i na początku XX wieku. Swoim zaangażowaniem zaś zapewniali sobie efektowną polityczną przyszłość. Jednym z głównych propagatorów idei jugosłowiańskiej był pochodzący z Chorwacji rzeźbiarz Ivan Meštrović - artysta ukształtowany przez tradycję południowosłowiańskich pieśni ludowych i oddziaływania śródziemnomorskie (pochodził ze Splitu), wykształcony w Wiedniu. Nie zgadzał się z polityką monarchii habsburskiej wobec Słowian zamieszkujących jej tereny; austriacką aneksję Bośni i Hercegowiny uważał za cios w słowiańską część poddanych. Ówczesne czynniki społeczno-polityczne oraz ideowa współmyślność nakierowały Meštrovicia na drogę współpracy z dynastią Karađorđeviciów ${ }^{25}$.

Tworzone by patronować wizualnemu budowaniu tożsamości wielonarodowej wspólnoty projekty Meštrovicia należą niewątpliwie do kanonu form artystycznych królewskiej Jugosławii. Artysta głęboko wierzył w programowaną tożsamość jugosłowiańską. W tym kontekście jednym z bardziej interesujących konceptów Meštrovicia pozostawał Vidovdanski hram - monumentalna świątynia jugosłowiańskości, która wedle założeń władzy miała stanąć na owianym mitem Gazimestanie, czyli miejscu, gdzie w 1389 roku rozegrała się bitwa na Kosowym Polu. Pomysł ten stoi na antypodach względem inicjatywy budowy Świątyni Świętego Sawy.

Gdyby przyjrzeć się słowiańskiej wspólnocie językowej, to w języku polskim również istnieje słowo „chram”26, które znaczy: „świątynia”, „dom”. Jednak wedle definicji, zawartych w Słowniku mitów i tradycji kultury Władysława Kopalińskiego, wyrazu „chram” nie powinno się odnosić do świątyń chrześcijańskich, ale raczej do świątyń pogańskich lub też świątyń starosłowiańskich ${ }^{27}$. W przypadku Świątyni Świętego Sawy (serb. Hram Svetog Save, pot. serb. Svetosavski hram) nie powin-

25 Zob. N. Makuljević, U ime jugoslovenstva: Ivan Meštrović u „,Novoj Evropi”, w: Nova Evropa 1920-1941. Zbornik Radova, ur. M. Nedić, V. Matović, Beograd 2010, s. 589-601; N. Makuljević, Ivan Meštrović. Od proroka do protivnika jugoslovenstva, dostęp online https://yuhistorija.com/serbian/kultu ra_religija_txt00c3.html, [dostęp: 15.04.2020].

26 Występowanie wyrazu odnotowuje np. A. Brückner w Stowniku etymologicznym języka polskiego, definiuje go jako chram, wymysł naszych modernistów; nie polskie to, lecz cerk. chram, chramina, 'dom', na całem Południu 'dom'i ‘świątynia', 'kleć', 'piwnica', czes. chrám, chrámina, rus. chromy, choromina (chram 'świątynia', z cerk.), ‘dom'(...)”, zob. A. Brückner, Stownik etymologiczny języka polskiego, Warszawa 1985, s. 183.

27 Za W. Kopalińskim: Chram - świątynia; wyraz pseudopolski, o fonetyce poludniowostowiańskiej i czeskiej; po polsku brzmiatby chrom; w jęz. rosyjskim jest to płd.-stow. cerkiewizm; używany u nas przez pisarzy pochodzacych ze wschodu (Zaleskiego, Ujejskiego, Kraszewskiego), a przejęty przez Konopnicka i Młoda Polskę; por. Gontyna; Witeź. Porównując z hasłem gontyna: Gontyna - światynia pogańska dawnych Stowian, Prosów i Litwinów, wyraz sztuczny, stworzony prawdop. ok. 1860 przez filozofa Bronisława Trentowskiego, autora Chowanny, modny pod koniec XIX w., fatszywie odtworzony przez adideację do gont z kroniki nm. XII w., w której świątynię pogańska Stowian pomorskich nazwano (lac.) contina, z kqcina, kąt; przen. też 'schronienie, przytułek, dom'; por. Chram; W. Kopaliński, Słownik mitów i tradycji kultury, Lublin 1997. 
niśmy go więc używać, chyba, że używalibyśmy go na prawach nazwy własnej. Natomiast w przypadku dzieła Meštrovicia użycie archaicznego wyrazu „chram” wydaje się uzasadnione. Świątynia jugosłowiańskości pozostawała iście pogańska i prasłowiańska w swoim zamyśle i charakterze. Przede wszystkim nie przynależała do żadnej z wielkich religii monoteistycznych, lecz do słowiańskiej wspólnoty, dla której Vidovdanski hram (Chram) miałby stanowić obiekt na wzór Panteonu czy Walhalli ${ }^{28}$. Sam projekt Meštrovicia stanowił mieszankę różnych stylów: elementy bizantyjskie łączył z detalami inspirowanymi starożytnym Egiptem czy też kulturą Indian.

O ile w przypadku pierwszych projektów Świątyni Świętego Sawy możemy rozpatrywać jedynie zewnętrzną formę architektoniczną obiektu, o tyle koncepcja południowosłowiańskiego Chramu stanowiła dzieło całkowite - ze szczegółową wizją jego wnętrza oraz zewnętrza. Meštrovć rozpoczął prezentację swojego konceptu poprzez występowanie z rzeźbami, mającymi być elementami konstrukcji ${ }^{29}$. Po raz pierwszy szerszej publiczności Vidovdanski hram został przedstawiony w 1911 podczas wystawy w Rzymie w pawilonie Królestwa Serbii (mimo że Meštrović powinien reprezentować wtedy Austro-Węgry), co należy traktować jako polityczną prowokację; prowokację powtórzoną kolejno w 1913 roku w Londynie i w 1914 roku w Wenecji. Stanowić ona będzie środek jugosłowiańskiej propagandy podczas wystaw w Wielkiej Brytanii w 1915 roku, gdy w tle rozgorzeje pierwsza wojna światowa ${ }^{30}$.

Bezimienne podczas wystawy w Rzymie rzeźby stały się przedmiotem dwutorowych dyskusji o celowej historyczności czy też intencjonalnej ahistoryczności dzieła Meštrovicia. Chorwacki historyk sztuki Vinko Srhoj sugeruje, iż rzeźby te stanowiły owoc twórczej wyobraźni artysty, lecz wraz z rozwojem i polityzacją idei jugosłowiańskiej przyporządkowano im występujące w ludowej mitologii imiona ${ }^{31}$. Serbscy badacze wskazują natomiast, że bezimienne rzeźby od początku przedstawiały postaci historyczne oraz bohaterów południowosłowiańskich pieśni ludowych (które przecież towarzyszyły Meštroviciowi od dzieciństwa - przyp. A.F.) ${ }^{32}$. Jednak, aby uniknąć skojarzeń ze stosowaniem agresywnej propagandy, Meštrović wpierw unikał jednoznacznych odniesień do mitu kosowskiego, którego rekonstrukcja mogła zostać uznana za bezpośredni hołd wielkoserbskiej ideologii politycznej. Dopiero wraz z procesem konstytuowania się jugosłowiańskiej idei państwowej odkrywał korzenie i myśl przewodnią kreowanej świeckiej religii, bezpośrednio odwołującej się, według niego, do wspólnoty, która w 1389 roku na Kosowie dokonała samopoświęcenia, samoofia-

28 I. Čolović, Vidovdanski hram, w: Smrt na Kosovu polju, Beograd 2016, s. 265.

29 Dzisiaj rzeźby Meštrovicia dostępne są w Muzeum Narodowym w Belgradzie.

30 I. Čolović, op. cit., 267-268.

31 V. Srhoj, Ivan Meštrović i politika kao prostor ahistorijskog idealizma, „Ars Adriatica” 2014, nr 4, s. 375 .

32 Zob. A. Ignjatović, Vidovdanski hram Ivana Meštrovicia, stvaranje Jugoslavije i paradoksi nacionalizma, w: Dan vredan veka, 1 XII 1918, red. Radovan Cukić, Beograd 2018, s. 87-92; I. Čolović, op. cit., 264-265. 
rowania. Według tej interpretacji, Vidovdanski hram stanowiłby zatem świątynię religii ostatecznej ofiary (serb. religija krajnjeg požrtvovanja) - świątynię religii Cara Lazara $^{33}$. Spoglądając na rzeźby jako fragmenty wizualnej teologii Chramu, można zrekonstruować poczet świętych tej religii i jasno stwierdzić, że należą do niego takie legendarne, znane z pieśni epickich postacie, jak Miloš Obilić, Srđa Zlopogleđa czy Kosovka devojka. Ten sposób reprezentacji stanowił również narzędzie legitymizacji rządów serbskiej dynastii poprzez powoływanie się na średniowieczne dziedzictwo; stanowił formę podświadomego utożsamiania jugosłowiańskości z reinterpretowaną w celach politycznych wersją tradycji-religii kosowskiej, która wywodzi się z rodzimego dla serbskich Karađorđeviciów uniwersum symbolicznego.

Bezspornym pozostaje, że mityczne w swoim wymiarze symbolicznym Kosovo polje należy ściśle do serbskiej pamięci zbiorowej i tradycji kulturowej. Przypadek Meštrovicia dowodzi zaś tego, jak percepcja mitu rezonowała w innych częściach Półwyspu Bałkańskiego. W rozumieniu chorwackiego rzeźbiarza bitwa na Kosowym Polu nie była tylko bojem jednego etnosu, jednej nacji, lecz wszechsłowiańskim działaniem. W odróżnieniu od tradycyjnego tj. „serbskiego” rozumienia, w kulturowoteologicznej interpretacji Chramu Kosowo pozbawione jest funkcji mitu założycielskiego. W tym przypadku, na co zwraca uwagę etnolog Ivan Čolović, przypowieść o Kosowie mówi o duchowym zwycięstwie narodu, który zapobiegł utraceniu swojej wolności i pierwotnej południowosłowiańskiej duszy ${ }^{34}$. Meštrović pojmował wspólnotę jugosłowiańską jako swoistą praikoniczną wspólnotę zakorzenioną w odległej, nieokreślonej przeszłości - zakorzenioną w czasach idyllicznego złotego wieku jedności sprzed podziałów etnicznych i religijnych; jako wspólnotę w znaczeniu pramatki, która poczęła wszystkie południowosłowiańskie etnosy - etnosy tej samej „rasy"35. (Co skądinąd konceptualnie wpisuje rozmyślania Meštrovicia w rozwijający się w tym okresie dyskurs o rasie i typologii bałkańskich narodów).

Akonfesyjne myślenie Meštrovicia o jugosłowiańskiej wspólnocie rozwiązywało częściowo kwestię Słowian muzułmanów. W czasach ciągłej deosmanizacji przestrzeni symbolicznej wynikła potrzeba zintegrowania tej grupy ludności z nowo kreowaną wspólnotą polityczną. W okresie międzywojennym teoria o obecności i duchowej działalności bogumiłów na terytorium średniowiecznej Bośni nabrała znaczenia, ponieważ wyjaśniała późniejszą łatwość w islamizacji miejscowej ludności. Zresztą sam Meštrović wiązał swoje pochodzenie z tradycją bogumilską, twierdząc, że właśnie $\mathrm{z}$ tej przyczyny również jego przodkowie przyjęli islam ${ }^{36}$.

Sztuka Meštrovicia swoiście wkomponowuje się też w problematykę i dyskurs dwudziestowiecznych badań antropologicznych, czyli w czasy, gdy antropolodzy po-

${ }^{33}$ A. Ignjatović, Vidovdanski hram, s. 85.

34 I. Čolović, op. cit., s. 271.

35 Ibidem, s. 272.

36 N. Makuljević, Ivan Meštrović. Od proroka do protivnika jugoslovenstva, dostęp online https:// yuhistorija.com/serbian/kultura_religija_txt00c3.html, [dostęp: 15.04.2020]. 
szukiwali źródeł kultury w obyczajach ludów pierwotnych - teoretycznie nierozwiniętych cywilizacyjnie - tak „obcych” Europejczykowi. Vidovdanski hram nawiązywał przecież do pierwotności, pogańskości, można by wręcz powiedzieć dzikości (a może nawet słowiańskiego barbarzyństwa?), ale wartościowanego pozytywnie jako źródło wspólnotowego etosu i politycznej witalności.

Pierwotny charakter i eklektyczna forma projektu Meštrovicia w swoisty sposób odwoływały się do wcześniejszego, zachodnioeuropejskiego zafascynowania ludowością i dziewiczością kultury Słowian Południowych. Świątynia Świętego Sawy stanowiła zaś całkowitą opozycję wizji jugosłowiańskiego (czy też - chorwackiego) artysty. Jej sakralny wymiar i bizantyjski styl nawiązują do spuścizny rozwiniętej cywilizacji - cywilizacji niejako wtórnej - rzeczywistości przetworzonej (ulepszonej, uwznioślonej i upiększonej) przez człowieka myślącego, nieowładniętego pierwotnymi instynktami.

Chram Meštrovicia nie należał do żadnej z wielkich monoteistycznych religii, tylko wizualizował imaginarium południowych Słowian, których tożsamość sama w sobie jawiła się jako świecka religia. Świątynia Świętego Sawy jako świątynia prawosławna była ekskluzywistyczna w swoim wymiarze, miała być symbolicznym darem jedynie dla części mieszkańców królestwa jugosłowiańskiego. Nieszablonowy pozostaje więc wniosek historyka sztuki Marka Stojanovicia i architekta Ivana Stanojeva, którzy we wspólnym artykule konstatują, że dzięki swojej formie architektonicznej, nawiązującej do powstałej w Konstantynopolu jeszcze przed schizmą (1054 rok) Hagii Sofii, belgradzka świątynia stanowiła próbę wypracowania kompromisu pomiędzy dwiema konfesjami - prawosławiem i katolicyzmem ${ }^{37}$. W obliczu licznych przejawów „bizantynizowania” serbskiej kultury i sztuki przełomu XIX i XX wie$\mathrm{ku}$, warto zastanowić się, czy wzorowanie się na archetypowej Hagii Sofii faktycznie można traktować jako jakikolwiek kompromis, czy wybór ten jest raczej wizualną afirmacją przynależności do postbizantyjskiego kręgu kulturowego i sposobem kreacji narodu jako „pierwszego wśród pierwszych” - autentycznego imperatora, który poprzez to odwołanie legitymizuje swoje prawo do „korony” Słowian Południowych. Skłaniałabym się ku takiej interpretacji.

Vidovdanski hram pozostawał estetycznym wyobrażeniem pierwotnej, słowiańskiej jedności. Chociaż krytycy dynastycznego centralizmu zarzucali, że za sprawą kosowskiego pierwiastka idealnie wpisuje się w wielkoserbską wizję, Karađorđeviciowie

37 M. Stojanović, I. Stanojev, Traženje nacionalnog identiteta Kraljevine Jugoslavije - od Vidovdanskog do Svetosavskog hrama, „Nasleđe” 2016, nr 17, s. 94. Należy też zauważyć, że serbscy badacze na problem patrzą z niejako odwróconej perspektywy - poszukują mechanizmów konstrukcji tożsamości jugosłowiańskiej, bazującej na elementach wszystkich kultur do niej się zaliczających, natomiast problematyka niniejszego tekstu skoncentrowana jest wokół procesów służących kreowaniu serbskiej tożsamości, przed powstaniem Królestwa i wewnątrz jego struktur, paralelnie do ideowego tworu zwanego integralnym jugoslawizmem. 
nigdy nie podjęli prób realizacji tej wizji artystycznej ${ }^{38}$. Sam Meštrović nie chciał być w żaden sposób łączony z programem „Wielkiej Serbii” (chociaż warto się zastanowić czy nieświadomie nie stworzył on jednak wizualnej reprezentacji Načertanija Iliji Garašanina ${ }^{39}$ ). Projekt artysty okazał się więc symbolicznym pomnikiem idei jugosłowiańskiej. Natomiast budowa serbskiej, rdzennie prawosławnej Świątyni Świętego Sawy została rozpoczęta, chociaż równie szybko wstrzymana przez drugą wojnę światową oraz późniejsze zwycięstwo komunistów. Ideologia bratstva i jedinstva (braterstwa i jedności) tymczasowo wygrała z religią srpstva ( $i$ jedinstva). Jednak Svetosavski hram nie zniknął całkowicie, został jedynie zahibernowany przez chyba nie do końca świadomych jego przyszłej mocy ideologicznej titowskich towarzyszy i skazany na oczekiwanie na „lepsze” czasy oraz bardziej sprzyjające warunki polityczne.

\section{BIBLIOGRAFIA}

Arhitektura Hrama, https://hramsvetogsave.rs/O-Hramu/Arhitektura-Hrama [dostęp: 15.04.2020].

Bandić Dušan, Narodno pravoslavlje, Biblioteka XX vek, Beograd 2010.

Brückner Aleksander, Słownik etymologiczny języka polskiego, Wiedza Powszechna, Warszawa 1985.

Čolović Ivan, Smrt na Kosovu Polju. Istorija kosovskog mita, Biblioteka XX vek, Beograd 2016.

Gil Dorota, Prawosławie. Historia. Naród. Miejsce kultury duchowej w serbskiej tradycji i wspótczesności, Wydawnictwo Uniwersytetu Jagiellońskiego, Kraków 2005.

Ignjatović Aleksandar, Ispred vizantijskog purpura: vizuelizacija nacije na Drugom vizantološkom kongresu u Beogradu 1927. godine, „Zbornik Matice srpske za likovne umetnosti” 2018, t. 46, s. 127 140.

Ignjatović Aleksandar, Između žezla i ključa: nacionalni identitet $i$ arhitektonsko nasleđe Beograda i Srbije u XIX i prvoj polovini XX veka, „Nasleđe” 2008, nr 9, s. 51-73.

Ignjatović Aleksandar, U srpsko-vizantijskom kaleidoskopu. Arhitektura, nacionalizam i imperialna imaginacija 1878-1941, Orion art-Univerzitet u Beogradu Arhitektonski fakultet, 2016.

Ignjatović Aleksandar, Vidovdanski hram Ivana Meštrovicia, stvaranje Jugoslavije i paradoksi nacionalizma, w: Dan vredan veka, 1 XII 1918, red. Radovan Cukić, Beograd 2018, s. 77-92.

Istorijat Hrama, https://hramsvetogsave.rs/O-Hramu/Istorijat-Hrama [dostęp: 15.04.2020].

Kadijević Aleksandar, Sveta Sofija u Carigradu kao uzor srpskih arhitekata novijeg doba, „Zograf” 2019, nr 43, s. 215-230.

Kadijević Aleksandar, Vizantijsko graditeljstvo kao inspiracija srpskih neimara novijeg doba/Byzantine architecture as inspiration for serbian new age architects, Galerija nauke i tehnike SANU, Beograd 2016.

Kopaliński Władysław, Stownik mitów i tradycji kultury, PWZN, Lublin 1997.

Makuljević Nenad, Ivan Meštrović. Od proroka do protivnika jugoslovenstva, https://yuhistorija.com/ serbian/kultura_religija_txt00c3.html [dostęp: 15.04.2020].

38 Nie znaczy to jednak, że jugosłowiańskie projekty Meštrovicia nie były realizowane - doskonały przykład jego wizji jugosłowiańskości stanowi Spomenik nepoznatom junaku na wzgórzu Avala.

39 Načertanije - dokument przedstawiający program serbskiej polityki zewnętrznej i polityki narodowej, napisany w 1844 roku przez Iliję Garašanina, ówczesnego ministra spraw wewnętrznych, zakładający zjednoczenie wszystkich ziem uznawanych za ,etnicznie serbskie”. 
Makuljević Nenad, U ime jugoslovenstva: Ivan Meštrović u „Novoj Evropi”, w: Nova Evropa 1920 1942. Zbornik radova, ur. M. Nedić, V. Matović, Institut za književnost i umetnost, Beograd 2010, s. 589-601.

Makuljević Nenad, Jugoslovenska umetnost i kultura. Od umetnosti nacije do umetnosti teritorije, w: Jugoslavija u istotrijskoj perspektivi, red. L. Perović, D. Roksanović, M. Velikonja, W. Hoepken, F. Bieber, Beograd 2017, s. 414-433.

Molè W<ojsław>, Sztuka Stowian Poludniowych, Zakład Narodowy im. Ossolińskich, WrocławWarszawa-Kraków 1962.

Pešić Branko, Godine Hrama Svetog Save, Beograd 1995.

Srhoj Vinko, Ivan Meštrović i politika kao prostor ahistorijskog idealizma, „Ars Adriatica” 2014, nr 4, s. $369-384$.

Stojanović Dubravka, Kaldrma i asfalt: Urbanizacija i evropeizacija Beograda 1890-1914., Udruženje za društvenu istoriju, Beograd 2012.

Stojanović Marko, Stanojev Ivan, Traženje nacionalnog identiteta Kraljevine Jugoslavije - od Vidovdanskog do Svetosavskog hrama, „Nasleđe” 2016, nr 17, s. 87-96.

Sudjic Deyan, Kompleks gmachu. Architektura władzy, thum. A. Rasmus-Zgorzelska, Centrum Architektury, Warszawa 2015. 